\title{
PRINT AS THE CONTEXTUAL FACTOR OF MODERN AGE
}

\section{ДРУК ЯК КОНТЕКСТУАЛЬНИЙ ЧИННИК ЛЮДИНИ НОВОГО ЧАСУ}

\author{
Vasyl Teremko ${ }^{1}$
}

DOI: https://doi.org/10.30525/978-9934-26-021-6-10

Abstract. This article traces the transformations of individual, caused by informational interventions in hisher mental world, intensified by the development of print as a technological centre of the Industrial Era media system, followed the explosion of consumer psychology, replacing individuality by the "mass person" perplexed by "fashion epoch". A humanistic ideal, self-sufficient, self-sustained individual appears in such worldview systems as a consumer. A set of individuals selected by specific criteria appears as the target audience, the mass consumer, chosen to buy everything from tastes and goods to ideologies, political doctrines, ways of life, fashion, government, friends, enemies and even war or peace.

The production of such consumers started with the phenomena of scaling and unification, intensified by the books-bestsellers, mass media, tabloids, glossy and glamorous magazines, entertainment television, pop music, blockbusters and TV series. Based on the investigation of individual and mass subconscious psychological mechanisms and impact techniques, taste and critical thinking was consistently destroyed, which drove to imposing absolute consumerism as continuously stimulated insatiability of needs, leading to the consumption loop, where requirements are impossible to satisfy. Intellectually simplified, spiritually exhausted media signals, aimed at the instinctively emotional spheres of individuals, steadily lowered the horizon of personal expectations and the thresholds of information accessibility, weakened critical thinking, blurred ethical filters, levelled tastes and transformed the audience into a mass.

\footnotetext{
${ }^{1}$ Dr. of Social Communications, Associate Professor of the Department of Publishing and Editing, Institute of Journalism of Taras Shevchenko National University, Ukraine
} 
Furthermore, despite the specific differences, this trend has penetrated all social and individual spheres.

Under the pressure of aggressive reality and communication campaigns, a holistic, harmonious, self-aware, intentional personality lost its value for itself. The process, begun in the New Age, was a kind of denial of its foundations and prepared an individual for the transition to the information age.

\section{1. Ветуп}

Друк як індустріальна технологія, орієнтуючись на значущі в Новому часі цінності раціоналізму й гуманізму, сформував медіасистему, яка орієнтувалася на розвиток людського в людині, творила гуманісттичні контексти й завдяки цьому відіграла потужну людинотвірну роль. Її центром була книга як генератор ідей, логоцентричних наративів, які розвивали пізнавальні можливості й духовний світ особистості, й завдяки цьому вона ставала цілісним й інтенційним суб' єктом буття.

3 часом на історичну арену вийшли медіа, які, спираючись на досягнення друку, апелювали до інших органів чуттів й інакше навантажували рецептивну систему особистості, роблячи їі метою і засобом комунікайних маніпуляцій, внаслідок чого вона втрачала онтологічну владу над собою.

Характер сучасної медіасистеми спонукає бачити не тільки технологічні аспекти й зумовлювані нею комунікаційні ефекти, а також їхній вплив на онтологію людини на різних горизонтах часу, щоб збагнути медійну зумовленість й актуальні прояви теперішніх антропних явищ.

Актуальність дослідження активована функціонуванням в сучасному соціумі потужних комунікаційних середовищ, які, базуючись на технології друку й на можливостях цифри, мають автономні й спільні авдиторії, разом і розокремлено працюють у сфері потреб, інтересів і цінностей людини, визначають їі світоглядні домінанти і поведінку.

Сучасний характер комунікації $є$ радикальним антропним викликом, в осягненні природи якого й дослідженні впливу на структури особистості методологічно й у прикладному сенсі важливе осмислення ролі друку в генерування антропної реальності людини Нового часу, яка готувала цифрову добу і в ній присутня. Ця міждисциплінарна наукова проблема зводить в одному предметному просторі пред- 
ставників різних галузей науки, зосереджених на роботі медіа й бутті людини. Пропоноване дослідження має об'єктом феномен друку як контекстуальний чинник людини Нового часу (Модерну), який зініціювавав потужний розвиток іiі сутнісних сил і можливостей, спонукав iii рух до нових засад індивідуального, колективного буття й наближав до цифрової реальності.

Метою дослідження є виявлення соціо- й антропотвірних ефектів друку як ініціативного чинника руху в людині ії сутнісних сил і впливу на різні підсистеми ії буття.

Реалізація зазначеної мети зумовила постановку таких завдань:

- довести неминучість соціокультурних й антропних змін у зв'язку 3 інтенсивним інтегруванням в читацький простір друкованого контенту, трансформацією характеру читання;

- визначити основні напрями впливу друку на розвиток ідей, світоглядних систем людини в медіареальності Модерну.

- розкрити сформовані друком джерела та механізми інформаційно-комунікаційного впливу на свідомість і поведінку людини.

Відповідно до мети і завдань застосовано методологічну систему, яку конфігурують:

- філософська методологія - сукупність пізнавальних принципів і підходів мисленнєвого осягненя медіареальності Модерну як середовища людського буття;

- цивілізаційний підхід - евристична зорієнтованість на встановлення причиново-наслідкових зв'язків між історично зумовленими фактами, процесами та явищами; соиіокультурний - розкриття кореляцій одиничних і загальних явищ доби; системний - погляд на медіаявище у множинності його підсистем, історичний - пізнання якісного руху медійних й анропних явищ у часі; синергетичний - дослідження медійного й анропного явищ в їхніх внутрішніх станах.

- ретроспективний аналіз - осягнення зумовленого друком руху світоглядних і ціннісних систем Модерну та їхнього прояву в бутті людини.

Наукова новизна роботи полягає в міждисциплінарному погляді на роль друку в генеруванні ідей, світоглядних й інтелектуальних систем Нового часу, становленні засобів впливу на свідомість, поведінку, саморозвиток і саморозкриття людини. 


\section{2. Прогресистські енергії Ренесансного культурного компромісу}

Друк як індустріальна технологія радикально збільшив масив й інтенсивність інтервування в культурний простір різнорідної інформації, що стимулювало духовну, світоглядну, художню й інтелектуальну працю новочасної людини. Усе це, зробивши Новий час епохою ідей, відкриттів і знань, виводило людину на поріг свободи, множинного вибору й різноманітних викликів.

На початку своєї історії друк потребував значно більше текстів, ніж могла запропонувати тогочасна європейська література, тому знаходив ïх у християнських Писаннях і набутках античності. Твори античних авторів, символічно полемізуючи із середньовічною ідеологією, кликали людину в профанний світ з багатоманітністю його стихій, характерів і пристрастей. I все-таки вони виводили в культурний простір новонародженої індустріальної доби мотиви й соціотипи минулого, через те не могли повноцінно наповнити тогочасні потреби - то був історично зумовлений культурний компроміс, оскільки інших ресурсів друк ще не мав. Свою роль вони зіграли, бо трималися на світських реаліях, людина в них більше належала собі, ніж людина Середньовіччя, однак і тоді вона знаходила пояснення багатьох реалій світу поза межами своєї волі, що було зумовлено язичницьким чи ранньохристиянським світоглядом. Історія зробила Ренесансну добу символічною зустріччю раннього християнства, католицизму і православ'я, поставивши європейську людину перед вибором духовної ідеології і значною мірою - ідейно-духовних джерел і шляху розвитку, що й відбулося: романським народам була ближчою давньоримська традиція; германські - вабила мораль раннього християнства, що згодом їх привело до протестантизму; народи слов'янські шукали себе або в римській, або у візантійської культурі.

Ренесанс виконав значно складнішу і значущішу роботу, ніж реверсно-прогресистське переведення середньовічної людини через античну культуру в Модерн. Наскільки було можливо, він задав нові траєкторії прочитання ранніх ідей людиною, яка мала незрівнянно багатші історичний досвід, можливості пізнання й вищу здатність вилущити 3 греко-римських культури важливі для неї сенси.

Людиноцентричні енергії, які репрезентували «батько гуманізму» Ф. Петрарка, «перший гуманіст» Дж. Бокаччо й уся світська культура, 
наповнивши людськими пристрастями тогочасну книжність, стимулювали феєрверк нових тем і жанрів. Світова культура завдячує Ренесансові мистецьким явищем класицизму, який поєднав чіткість, чистоту, ієрархічність, гармонійність художніх форм зі свободою вибору. Становлення нових жанрів звузило ареал усності, роз'єднавши поезію та спів, прозу й ораторства, літературну драму й театр.

Найпомітніші сліди Ренесанс залишив у філософії, літературі, мистецтві, політичній і педагогічній думці. Запропонувавши геліоцентричну модель світу (М. Коперник), він поставив питання про людину як мікрокосм у іiі відношеннях із Макрокосмом (Всесвітом), відмовився вважати іiі уособленням гріха, що церква розцінила як посягання на теоцентризм, всеосяжність віри та ії духовну владу. Серед мислителів зринали ідеї людини як вищої цінності, iї рівнодостойності незалежно від «крові» та майна, а також іiї права на саморозуміння, гідність і самовладність. Усе частіше йшлося про розум і творче мислення, працю і саморозвиток як передумови досягнення людиною досконалості й повноти життя. Погляд на неї як центр світу, найвищу цінність і мету вилився в антропоцентризм і гуманізм як світоглядні орієнтації. Не обходилося і без світоглядних крайнощів, які привели до ідеї богорівності людини й титанізму, який обстоював безмежність її сил i розуму. I все-таки Ренесанс вростав у культуру завдяки світоглядним компромісам, що підтверджує ідея «двоїстої істини»- автономності істини віри й істини розуму.

Та доба була небезконфліктною: людина відчувала й бачила, як зникає звичний для неї світ, змінюється робота органів чуття в його сприйнятті й не могла знайти собі місця в нових реаліях [8, с. 25-48]. Ïї напруги дослідники (К. Поппер, М. Мак-Люен) відчитують у драмах Шекспіра, а екзистенційну метафору Короля Ліра інтерпретують дотепер: «Цей світ занадто круглий, його треба зробити трохи пласкішим» - вона показала, наскільки конфліктними й болісними бувають зустріч і «взаємопроникнення цивілізацій» [16; 15]. Плаский світ - це світ рівних можливостей, а Шекспір і гадки не мав, що слова його героя через п’ятсот років працюватимуть у назвах глобально відомих книг: «Світ плаский» (Т. Фрідман), «Новини пласкої землі» (Н. Дейвіс).

Друк надав потужності започаткованій письмом культурі візуального, що, яскраво вибухнувши в естетиці бароко, розщедрилася 
простором для візуально ефектних форм в архітектурі, малярстві й літературі. Радикально розширивши спектр світських ідей, ренесансний друк послідовно скорочував відстань між змістом того, що вона читала, і тим, як жила. Не відсторонюючи іï від притаманних християнській книзі відсилання душі й думки до Бога, він давав їй змогу в різних вимірах бачити земне. Більші наклади й оптимізування форматів робили книгу дешевшою, зручнішою в користуванні й навіть супутником у дорозі. Вона ставала доступною не тільки аристократії, а й середнім верствам населення, з часом - масовим товаром. Книга в своїй багатоманітності атестувала прагнення до освіти й освіченість, духовну позицію, місце в культурі, інтелектуальну шляхетність.

Розвиток новочасних культурних і світоглядних систем не був послідовно прогресистським. Секулярні ідеї змагалися за вплив на формування картини світу з релігійними; васальну психологію витісняв дух підприємництва; дворянина заступав промисловець; неподалік людини плуга випрямлювалися люди професій. Усвідомлення людиною своєї самості змінювало платформу соціальних структур, яку все менше цементували воля сюзерена й покірність васала. Індивідуальна людина вчилася шукати сенс життя завдяки власній розумовій активності, й уже цим посягала на стійкість скріплених страхом і вірою людських єдностей. У цій світоглядно й екзистенційно збуреній драмі виростала роль нової книжності, в якій активна, й самодостатня особистість, покладаючись на свою працю та співпрацю з такими, як вона, знаходила необхідні знання й відповіді на повсякденні питання, довіряючи їй як джерелу правди. Непохитним залишався пріоритет книги як джерела істини.

\section{3. Друк як чинник світогляду й ментальності людини індустріальної епохи}

Середньовічна світоглядна система отримувала удари не тільки від розпросторюваних друком нових ідей, а й руйнувалася зсередини. Найвідчутніше вразила її Реформація, яку зініціював католицький священник і релігійний мислитель Мартин Лютер, виразивши настрої рівнодостойності людини в питаннях віри і свободи совісті. Обурившись змістом булли, яку 18 жовтня 1517 року видав Папа римський Лев $\mathrm{X}$ щодо продажу індульгенції на відпущення гріхів, М. Лютер через три- 
надцять днів завершує свої «95 Тез», у яких заперечує правомірність цього акту Святого Престолу, обстоює недоторканність Священного Писання й обгрунтовує принципи, які заклали ідейну основу Реформації: тільки Біблія є Богонатхненним Словом Господа, самоочевидним і відкритим для кожної людини, і ніщо, крім віри, не може бути підставою для відпущення гріхів. Вихід у світ «Тез» масовим накладом (1520 р.) німецькою мовою збурив дискусії не тільки в церкві, а почав всезагальний рух Реформації. Лютера залякують, шукають способи 3 ним домовитися, а коли все це виявилося марним, Папа відлучає його від церкви. Невгамовний Лютер перекладає німецькою Біблію, видаючи іiі частинами, а активно виступає 3 публіцистичними творами. Головне в них - людина, Бог і Богонатхненне Слово, гріх і прощення; все інше, чим завершилася Реформація, зробили енергії часу й нові суспільні сили. Гуманісти знайшли в ній ідею людини, вільнодумні дворяни, лицарі, інтелігенція - можливість послабити контроль церкви над їхнім життям, молодий індустріальний клас - ідею духовного сенсу діяльності й прагматичного індивідуалізму. Ця історична ситуація ілюструє силу масово розповсюдженого слова, що за тодішніх обставин міг зробити тільки друк.

Вихід у світ німецькомовної Біблії (перший наклад у 1534 р. чотири тисячі примірників) дав змогу людині читати Боже Слово і спілкуватися з Богом своєю мовою. Це зріднювало ііі з людьми, які також нею зверталися до Бога, і давало віру, що Він може почути кожного його ж мовою. Цей епохальний соціокультурний поворот започаткував шлях людини до національної єдності, на становлення якої працювало багато соціокультурних і духовних чинників, а роль друку серед них була однією з провідних.

Інтерес до Біблії рідною мовою набирав у Німеччині сили: в 1534-1574 pр. іiі було видано більше чотирьохсот разів сумарним накладом понад сто тисяч примірників. Лютер, як стверджує Б. Андерсон, став першим перекладачем і автором бестселерів, інтерес до яких значною мірою визначало його прізвище [1, с. 57-61]. За тієї ситуації зійшлися його релігійно-реформаторські інтенції, талант до письма, інтереси підприємницьких і народницьких сил, а також капіталістичного друку, який був готовий до такого виклику й максимально використав свій шанс. Нова етична система виводила на передній план 
кваліфіковану, відповідальну, соціально амбітну особистість, яка, сповідуючи пуританську етику протестантизму, формувала світоглядно-ментальні основи капіталізму, що спирався на ефективну економічну поведінку й базовані на праці, а не на походженні пріоритети, соціальний портрет якої виразно виписав М. Вебер («Протестантська етика і дух капіталізму»). Реальність переконувала, що народні мови можуть бути мовами книг, друку, і це їх виводило з побутової сфери у простір духу й високої культури. Реформацію підхопили інші народи, що розпочало потік соціокультурних, економічних, політичних і геополітичних процесів, які сформували політичну карту й етос Європи.

Відстоювати католицьку модель світу в нестабільній Європі, а також позиції латини як універсальної мови взявся ідеолог Контрреформації іспанець Ігнатій де Лойола, який у 1534 р. заснував чернечу громаду (орден єзуїтів) «Товариство Ісуса». Цю сторінку історії можна було б перегорнути, якби не кілька обставин: Ігнатій Лойола, маючи досвід «терпіння і читання», спеціальних духовних практик і розпізнавши започаткований письмом, прискорений друком і розширений просторово рух людства до візуальної цивілізації, винайшов психотехнологію переконування й спрямування активності людини, 3 чого почалася пропаганда: пробудити в діалозі з нею внутрішній зір, візуальні образи й, спаралізувавши внутрішній спротив, добитися потрібного реагування на комунікаційні стимули. Психологічно занурившись у задану реальність через активування чуттів (слуху, зору, нюху) й візуальне асоціювання звуків, форм, запахів із уявлюваним об'єктом, людина втрачала владу над своїми мисленням і поведінкою [12, с. 423-428], і цю владу перебирав над нею вишколений і вправний маніпулятор.

В епоху усності зорову роботу переважали слухова й нюхова, писемність почала перерозподіляти їхні навантаження на користь ока, а друк остаточно надав зорові пріоритет, на підставі чого I. Лойола, як зауважив Р. Барт, сформував візуальну мову комунікації. У Ватикані силу методу Лойоли розпізнали чи не одразу, і вже 22 червня 1622 року було створено Конгрегацію пропаганди при Святому Престолі. Мабуть, із цим пов'язана й участь братів ордену в роботі Радіо Ватикану.

Максимально скористалася цією психотехнологією тоталітарна пропаганда: Гімлер формував СС за моделлю єзуїтського ордену; Геб- 
бельс, будучи бібліофілом, усе-таки віддав перевагу в пропагандистській роботі радіо, яке, «структуруючи день» (Г. Інніс), мобільніше за книги й газети; Сталін тримав при собі письменників, режисерів, композиторів і виконавців, цинічно маніпулюючи ними і примушуючи їх маніпулювати суспільством - не спроста п’єсу М. Булгакова «Дні Турбіних» він дивився більше десяти разів, коментуючи іiї з різних приводів і за різних обставин на користь «сили більшовиків». Згадані вершителі тоталітаризму пройшли через єзуїтські колегіуми, де ретельно вчили візуального стимулювання чуттів, технологій ввергнення людини в стан адепта, доведення іï до екстазу чи ввергання в страх. I така ще деталь: «Майн Кампф» Гітлера, за однією версією писав, за іншою - редагував, єзуїтський священник Штемпфле. Щоправда, не всі єзуїтські вихованців саме так увійшли в історію - Вольтер, Мольєр, Декарт, Б. Клінтон, в Україні - П. Скарга, Б. Хмельницький, I. Мазепа, П. Орлик, Й. Сліпий є виразниками зовсім інших ціннісної системи й моделі діяльності. Лойола створив матрицю, «яка визначала мислення й поведінку людини» [12, с. 418-421], тим він був цікавий режисерові С. Ейзенштейну, структуралістові Р. Барту, біхевіористам Д. Канеману і Р. Талеру, плеяді дослідників А. Александеру, А. Темкіну, Г. Почепцову та ін. Щупальця цієї технології нагадують про себе і в сучасній комунікаційній реальності.

Контрреформація не змогла зупинити розпочаті М. Лютером процеси. Борючись за відновлення позицій католицизму й латини, вона розпалила ще потужнішу дискусію, яка посилила релігійне вільнодумство й світоглядні пошуки за межами католицького віросповідання, що завершилося виокремленням протестантизму. Світоглядна постава і ментальність нової європейської людини унеможливлювала відновлення цілісності католицької церкви й всюдисущості латини, на часі були розгалуження християнства, секуляризація, розвиток національних мов, держав, книжності й ідеології націоналізму, які живив стимульований капіталістичною підприємливістю друк [1], розвиваючи ключові свої продукти (книгу, газету, журнал) і створюючи передумови для інституційного утвердження видавничої справи з усіма їі підсистемами.

Завдяки поширенню друком просвітницького культу знань у XVII-XVIII ст. радикально змінилося розуміння світу й онтології 
людини (сутності, призначення, прав, свобод і гідності, ролі розуму, знань і науки в іiі вдосконаленні й прогресі суспільства). Ці процеси зініціювали теорія природного права та природного закону, які дали поштовх ідеології лібералізму (право людини на свободу й приватність), раціоналізму (розум, освіта й виховання - джерело розвитку людини, справедливого влаштовування світу), сцієнтизму, що поставив понад усе наукову істину.

Просвітництво урізноманітнило розпочатий у Ренесансі гуманітарний дискурс. Його розмислову панораму окреслювали ідеї: зовнішнього (експеримент) і внутрішнього (провидіння) досвіду; чуття як первинної форми істини («Немає нічого в розумі, що не пройшло через чуття»); звільнення розуму від хибних настанов - «ідолів», «привидів» свідомості, а також невігластва, що подає себе як знання (Ф. Бекон); пріоритету в пізнанні розуму, мислення - «Мислю, отже існую» і раціонального (картезіанського) методу: «починати з простого й очевидного», поділяти об'єкт дослідження на частини, послідовне, безперервне мислення, опора на чіткі й безсумнівні положення (Р. Декарт); природності егоїстичних мотивів діяльності людей (війни всіх проти всіх) і ролі суспільного договору в облаштуванні їхнього співжиття (Т. Гоббс); походження знань із досвіду, який залишає в розумі «свої письмена», Божественності природних прав людини на життя, свободу і власність, суверенітету народу і правомірності силової зміни несправедливої влади (Дж. Локк); єдності чуттів, мислення, здорового глузду, внутрішнього (душевного) і зовнішнього (чуттєвого) досвіду; людини як продукту середовища, первинності суспільних відносин у породженні конфліктів (Д. Дідро); «просвіченої» влади, рівності перед законом громадян (Вольтер); спеціалізації діяльності як самовідчуження людини від себе ( Ж.-Ж. Руссо); відчуження людини від власності (К. Маркс). У намаганнях осмислити нерозв'язані тогочасною філософією проблеми І. Кант вийшов на обгрунтування чистого (не пов'язаного з чуттям) і практичного (морального) розуму, а також категоричного імперативу як фундаментального морального принципу, суголосного із Золотим правилом моралі (Конфуцій, Христос). Сукупність ідей про людину, їі дух, розум, розмислову і творчу діяльність, світ іiї культури задали вектор духовних, естетичних пошуків людини Модерну, допомагали їй розкрити свої сутнісні сили і витерпіти випро- 
бування, яких багато впало на неї в Новому часі. На ії користь працювали ідеї, що високо підносили розум, людське в людині, безконечність ii потреб і можливостей.

Це був час філософів, ідеологічних світоглядів і політичних ідеологій (консерватизм, лібералізм, націоналізм, комунізм, анархізм). Його інтелектуально-мисленнєвий плюралізм дотепно ілюструє одна із дискурсивних ситуацій: тезу Бекона «Немає нічого в розумі, що не пройшло через чуття» дотепно підредагував Г. Лейбніц: «...крім витворів самого розуму», на що І. Кант знайшов примирливо-компромісне: кожне знання як надбання розуму починається з чуттів і розмислової активності людини $[13 ; 15]$.

Активізм просвітників не був марним: завдяки їм пожвавилося вільнодумство, виплеснувши свої енергії на сторінках періодики, яка вже була помітним чинником культурного життя, в публічних аудиторіях (клубах, книжкових кав'ярнях, літературних салонах). Культурною нормою стало читання «за стінами» - в громадських чи приватних бібліотеках. Потужну увагу отримала світська література як засіб творення нових типів героя в приземлених життєвих ситуаціях, інтерес до якої активізував публічні дискусії, що виводило на індустріальний горизонт видавничу справу, розширювало ареал масового читання. Парадоксальний феномен того часу - критиковані за низькопробність тексти «океану історій», які прилучали до читання представників неелітарних верств і вже цим виконували свою місію в культурі.

Динамічно співіснували й змінювали одна одну естетичні системи, впливаючи на світогляд, духовний світ мільйонів, узгоджуючи їхні очікування й поведінку. Просвітництво дало літературі філософську повість і роман виховання. Елементом культури стали бібліотеки інтелектуалів, промисловців, людей професій. Європейські видавці навчилися обходити цензуру, друкуючи книги в Англії й Нідерландах, де контроль за їхнім змістом вже не був таким огульним, що зробило ці країни лідерами друку.

Тогочасне розуміння людини фіксують романи Д. Дефо «Робінзон Крузо» і Дж. Свіфта «Мандри Гуллівера». «Робінзон Крузо» виводить на перший план буденне мислення і прикладні знання, вміння адаптуватися до обставин, налагоджувати стосунки й діяти, покладаючись на розум, волю й спілкування. «Мандри Гуллівера» - про недоречність 
гордості, бо можливості людини відносні й залежать не тільки від неї: за однієї ситуації Гуллівер - велетень, за іншої - ліліпут, хоч насправді ніяких змін із ним не відбувається. Обидва романи вважають опозиційними концепціями полеміки про людину.

Ще одна заслуга друку - демократизація знань, які втрачали приписаність до елітарних кіл. Індустріальний капіталізм, потребуючи грамотних працівників, розвивав освіту, а освічені люди знаходили бібліотеки і книги, щоб погамувати спрагу читання і знань. Окремі з них переходили на вищі щаблі соціальної стратифікації, стаючи людьми професій, вибираючись на вершини науки, літератури й мистецтва, започатковуючи бізнес на інтелектуальній основі.

У тогочасному світі рух наукових ідей був не швидшим руху поштових карет, а обсяг наукової інформації з певної галузі безпроблемно архівувала пам'ять ученого. Інтерес до знань й обміну науковою інформацією зініціював неформальну єдність «Республіка листування», яка заклала епістолярну традицію, відчутну ще в XX ст. Яскравий iï приклад - філософський трактат із математичного аналізу Г. Лейбніца, написаний у формі послань дамі; всього за ним значиться п’ятнадцять тисяч листів.

Інтелектуальні запити, розвиток науки і друк дали новий тип виданьнауковий журнал, що заявив про себе 1665 року в Парижі («Щоденник учених»), в Англії («Філософські операції»), а через п’ять років - у Німеччині («Miscellanea Curiosa» («Цікавий інший»). Спершу він був «універсальним» - публікував не систематизовані матеріали, а потім відбулася спеціалізація за характером знань, напрямами творчості, жанрами, категоріями читачів, й уже через кілька десятиліть Свропа мала літературні (Франція, 1684 р.) й жіночі (Англія, 1693 р.) журнали. Подібні процеси відбувалися і з газетами. А найпотужніше явище, на яке спромігся тогочасний друк, - зініційована Д. Дідро «Енциклопе́дія, або́ Тлума́чний словни́к нау́ки, мисте́цтва й реме́сел», якій він віддав двадцять років (1751-1772) праці, залучивши до співпраці Вольтера, Г. д’Аламбера, П. Гольбаха, Ш.-Л. Монтеск'є, Ж.-Ж. Руссо та ін. Перше двадцятивосьмитомне (17 томів - тексту, 11 - ілюстрацій) видання, що побачило світ накладом 4250 примірників, мало 71818 статей; з часом Енциклопедія розрослася до 166 томів. 3 науковою книгою і періодикою як дітищем друку асоціюються слова М. Карамзіна про нього як 
про один із головних етапів розвитку розуму й В. Вернадського - про те, що історія науки почалася з книгодрукування.

\section{4. Нові інструменти невидимої влади над людиною}

Будь-яке порубіжжя - якщо не злам, то надрив чи крутий вигин у суспільній думці, мистецтві й життєсвіті людини, які фіксують рух iï самобуття. Порубіжжя XVIII-XIX ст. знало і втому від ренесансно-просвітницького логоцентризму, раціоналізму, тому його хитнуло до діонісійської наповненості життя, романтичних поривів, небуденних переживань і пристрасних учинків непересічних натур. На позиціях чуттєвості тримався й сентименталізм як стильова тенденція.

Радикально замахнулася на раціоналізм «філософія життя», концепти якої ставлять у центр пізнання інтуїцію, проголошують волю самопородженою силою (А. Шопенгауер). Ідею волі Ф. Ніцше інтерпретував як волю до влади й втілений у надлюдині культ сили: «Дивіться, я - передвісник блискавки і важка крапля із хмари, але ім'я тої блискавки - надлюдина» [9; 15]; «Людина - це линва, напнута між звіром і надлюдиною линва над безоднею» [9; 13], - проголосив він. - «Настає той час, коли людина поставить собі за мету саму себе. Настає той час, коли людина посіє зерно найвищих своїх сподівань [там же]... Настає час того, кого найбільше зневажають, того, що вже не зможе зневажати себе» [9; 16]. У пристрасних текстах Ніцше міг знайти себе будь-хто, невдоволений своїм становищем, неспроста в багатьох країнах його ідеї підхопили 3 різними намірами, ціннісними системами і в різний час суспільні сили, які слід в історії залишили теж різний, здебільшого - трагічний.

Пізнавальне заглиблення людини у світ розширювало і владу над нею. Досягнення психології відкривали доступ до іiі мотиваційно-поведінкової системи, робили інформацію й медіа інструментами управління іï думками, бажаннями й діяльністю. Людина, отримавши дивовижні можливості оволодіння чужими емоціями й умами, втрачала контроль над власною самодостатністю. Особливо доклалися до цього на порубіжжі XIX-XX ст. біхевіоризм і психоаналіз.

Біхевіоризм (Дж. Вотсон, Е. Торндайк, Б. Скіннер - необіхвіоризм) тлумачив людську поведінку за формулою «стимул - реакція», залежну від підкріплення (позитивного, негативного), яке може іiї посилювати чи ослаблювати, активувати зростання або деградацію особистості. 
Пізніше цю модель було доповнено елементами «мета» $\mathrm{i}$ «потреба». Ігноруючи явища внутрішнього світу, він зосередився на психологічних стимулах і доступних для спостережень, математичного аналізу об'єктивованих проявів поведінки: характер стимулів є основою прогнозування реакцій, за якими можна ретроспективно реконструювати стимули. Біхевіористські методи прогнозування, моделювання, конструювання культурної реальності застосував у бібліопсихології М. Рубакін: «Кожен об'єктивно досліджений читач може бути використаний як реактив на книгу» [14, с. 101]; «Кожні об’єктивно дослідженні книга, фраза, слово можуть бути реактивом на будь-якого читача» $[14$, с. 103$]$; «Кожна літературна форма має свій психічний корелят, діючи як подразник на читача чи слухача» [14, с. 133].

Психоаналіз (3. Фройд) зосередився на невидимих світах особистості - конфліктах духовного й інстинктивного на підсвідомому, свідомому й надсвідомому рівнях, а також на неусвідомлюваних (несвідомому, позасвідомому) процесах і станах, що впливають на емоційне життя і поведінку. Людина - складна енергетична система, яку розриває внутрішня напруга як конфлікт свідомого і підсвідомого. Його подолання можливе завдяки витісненню деструктивних енергій iз свідомості у підсвідомість і випрацюванню їх у творчій активності (сублімації). Тому психоаналітик повинен мати досвід самоспостережень і вміння знаходити в мистецьких творах сублімовані інтерпретації авторами власних невротичних станів. Історії психічних проблем 3. Фройд сприймав як новели, а творчість Шекспіра й Достоєвського як джерело невротичної психології.

Психоаналіз 3. Фройда, вивернувши психіку людини, показав правду про неї, яку вона ховає і від якої ховається. Першим із психоаналітиків пішов своїм шляхом А. Адлер, побачивши джерелом неврозу недостатню реалізацію потягу до влади, який проявлясться як компенсація пережитого в дитинстві відчуття власної неповноцінності (комплекс неповноцінності). 3 позицій аналітичної психології К.-Г. Юнга несвідоме значно складніше, оскільки поєднує індивідуальні тенденції й колективні (успадкований загальнолюдський, національний досвід) первісні образи (енергетичні згустки) - архетипи. Життєдіяльність індивіда пов'язана з архетипними уявленнями як синтезом утворень свідомості й «голосу» первісних образів. 
Проблематика несвідомого певною мірою була відома давно. I. Франко у трактаті «Із секретів поетичної творчості» згадав Софокла й Евріпіда як авторів, чиї герої його владу над собою знали. Ця ситуація натякає на необхідності стриманого прочитання тези М. МакЛюена, що друк відкрив у людині підсвідоме - коректніше думати, що він (мовчазне читання, рефлексія) посилив у людині його голос.

Психоаналіз дав літературі інструмент проникнення в глибини психіки. Комунікаційним технологіям він дав ключі від індивідуальної та масової свідомості. Силу управління несвідомим розпізнав Е. Бернейс, побачивши в психоаналізі й психології мас Г. Лебона інструмент влади над колективною свідомістю як «інженерію згоди» й започаткувавши соціоінженерний напрям - зв'язки з громадськістю (паблік рілейшнз). Людей, які «знаються на розумових процесах і соціальній структурі мас», створюючи «необхідні ідеї», «тягнуть за мотузки, що йдуть до суспільної свідомості», і на цій основі програмують їі, нав’язують смаки й поведінку, він назвав «невидимим урядом». Їхня діяльність набула сили 3 «появою друкарського верстату, газет, залізниць, телефону, телеграфу, радіо та аероплану», завдяки яким «стало можливим швидко, навіть миттєво, поширювати ідеї /.../ на будь-яку відстань, будь-якій кількості людей /.../, у результаті чого «люди, що мають спільні інтереси, отримують змогу об'єднуватися та спільно діяти, перебуваючи при цьому за тисячу миль одне від одного» [4-7], - писав він у сенсаційній для його часу праці «Пропаганда», що побачила світ у 1928 р.

Знання закономірностей компенсаторних реакцій на неусвідомлені бажання зробили незахищеними від інформаційних інтервенцій задля бажаних реакцій позасвідомі структури психіки. Саме такими є неінформаційні засоби (кампанії) формування інформаційного контексту 3 асиметричним ефектом. Їх Е. Бернстейн використав у просуванні ідей, стилів життя й товарів. У нього вчилися найбільші маніпулятори свідомістю, а його «Пропаганда» була настільною книгою Геббельса. Це один із прикладів того, що друк як гуманістична на його початках комунікаційна технологія нерідко був і запереченням самому собі, оскільки долучався до систем маніпуляції людською свідомістю, волею й поведінкою.

Двадцяте століття, вивершуючи індустріальну епоху, інтенсифікувало комунікаційні механізми управління цільовими аудиторіями й 
ринками. Сформоване урбанізацією і друком (масове читання, мас-медіа і масове мистецтво) масове суспільство, вирвавши людину із властивих «епосі звичаю» (Г. Тард) традиційних соціальних зв'язків і форм колективності, кинуло іï у вир комунікаційних технологій, де розум стає мішенню медіаекспансії, внаслідок чого вона втрачає суверенітет над собою, стаючи «людиною в натовпі», підвладною «стадному інстинктові» (Ніцше) й залежною від лідера (вождя, глашатая, провідника). Таке становище нагнітає ілюзії причетності й захищеності, усереднює й анонімізує індивідуальність, уніфікує, синхронізує переживання й очікування, реакції та дії, навіть уподібнює вирази обличь.

Продукування такої соціопсихологічної картини розпочав індустріальний друк своїми ефектами уніфікації й масштабизації, метою яких став бестселер як чинник бізнесового успіху. Зорієнтована на низинні смаки його продукція разом із іншими медіасистемами (телебачення, серіали, реклама) нав'язувала ненаситність потреб, що заганяє людину в конвеєр споживацтва (конс'юмеризм), де неможливо вгамуватися в їх задоволенні. Конс'юмеризм витворив світоглядно крихку, морально аморфну, меркантильно ненаситну, з ослабленими емоційними інтелектом і волею, дивовижними невмінням бачити себе й лінню думати людину. Вона легко стає одиницею «зграї й стада», електоратом, втрачаючи здатність бути людиною позиції, вибору і шляху.

Спрощені інтелектуально й духовно вихолощені медійні сигнали, націлені на інстинктивно емоційні сфери особистості, знижували горизонт її очікувань і пороги доступу інформації, ослаблювали критичне мислення, розмивали етичні фільтри, нівелювали смаки й робили публіку масою. Масова свідомість і масовий споживач стали центром бізнес-інтересу індустріального класу, масові аудиторії брала під контроль політика. У медійну сферу прийшли технології, які привчили масову людину жити у світі з розмитою культурою, в якому ціннісні основи Модерну і самозорієнтована на них людина, почувається чужою.

\section{5. Висновки}

Шлях медіумів і медіа, значною мірою розкриваючи цивілізаційну історію та історію людини в культурі, дає ключі для розуміння всього, що впливало на неї, на що впливала вона і як це змінює іiі та світ. 
Базована на потенціалі друку медіасистема Нового часу вела людину з холодного пуританського Середньовіччя в простір гуманізму й раціоналізму, де вона постає тотожною собі, органічною у світі природи й активною у творенні світу культури. Цьому в ранньому Модерні прислужилися дук античних творів (Ренесанс) і стимульований ним розвиток освіти, науки, літератури й мистецтва.

Розповсюдження продуктів друку, серед яких ставало все більше світських текстів, стимулювало вибух читання та його перехід в усну («мовчазну») форму, що розширило пізнавальні горизонти людини й доклалося до формування наділеного критичним мисленням самоусвідомленого читача, який став соціокультурною основою реформаторського руху в Свропі. Употужнені друком ідеї Реформації дали людині, яка непросто вибиралася із Середньовіччя, світське бачення істини та правди, реалій життя і себе в житті, відкрили їй нові можливості самоздійснення завдяки освіті, розвитку науки та філософії (Просвітництво) становленню національних мов, спільнот і держав.

Друк виявив себе потужним агрегатором, акумулятором і транслятором ідей, знань і духовно-інтелектуальних цінностей, зумовив типологічний розвиток медіасистеми, символічним центром якої тривалий час була книга (друкована сторінка тексту), яка зосереджувала на собі очікування й увагу людини, визначала зміст їі медіабуття й буття у світі. Цим значною мірою зумовлений тріумф гуманізму, раціоналізму і базованих на їхніх ідеях світоглядних та естетичних систем. Саме тієї пори новонароджена видавнича індустрія витворила бестселер як галузевий феномен. Центрована увага на продуктах друку зробила його ключовим чинником розвитку культурного порядку денного Нового часу.

За законами діалектики друк спрацював і як заперечення структур, явищ, норм і цінностей, які впроваджував, що проявилося в розвитку й застосуванні технологій впливу на людську свідомість, підсвідомість і поведінку. А стимульований ним розвиток медіазасобів і медіатехнологій спричинився до його витіснення з центру медіасистеми.

Сучасна медіаситуація проблематизує онтологію людини і ставить iii перед новими соціокультурними викликами - їх генерували медіареальність зрілого Модерну, постмодерну й актуалізує медіареальність інформаційної доби. 


\section{Список літератури:}

1. Андерсон Б. Уявлювані спільноти. Міркування щодо походження й поширення націоналізму / пер. 3 англ. В. Морозов. Київ : Критика, 2001, 272 с.

2. Бернейс Едвард. Пропаганда. Київ : видавничий дім «Сварог», 2020, 128 с.

3. Виндельбанд В. История философии / пер. с нем. П. Рудин. Київ : НикаЦентр, 1997. 560 с.

4. Гуревич С. Философская антропология : учеб. пособие. 2-е изд., стер. Москва : Омега-Л, 2010. 607 с.

5. Дойч К. Народи, нації та комунікація // Націоналізм: народи, нації та комунікація [антологія; упоряд. О. Проценко, В. Лісовий]. Київ : Смолоскип, 2006. C. 317-322.

6. Кастельс М. Информационная эпоха: экономика, общество и культура. Москва : ГУ ВЩЭ, 2000. 264 с.

7. Кримський С. Б., Павленко Ю. В. Цивілізаційний розвиток людства. Київ : Фенікс, 2007. 316 с.

8. Мак-Люен М. Галактика Гутенберга: Становлення людини друкованої книги; [пер. $з$ англ. А. А. Галушки, В. І. Постнікова]. 3-тє вид. Київ : НікаЦентр, 2011. 392 с.

9. Ніцше Ф. Так казав Заратустра; Жадання влади // пер. 3 нім. А. Онищка, П. Таращука. Київ : Основи, Дніпро, 1993. 415 с.

10. Потятиник Борис. Медіа : Ключі до розуміння. Серія : Медіакритика. Львів : ПАІС, 2004. 312 с.

11. Погорілий Олександр. Макс Вебер i його класична праця / Протестантська етика і дух капіталізму / пер. $з$ нім. Погорілий О. Київ : Наш формат, 2018. $216 \mathrm{c}$.

12. Почепцов Георгий. Пропаганда 2.0. Харьков : Фолио, 2018. 796 с.

13. Рассел Б. Історія західної філософії / Пер. 3 англ. Ю. Лісняка, П. Таращука, Київ : Основи, 1995. 759 с.

14. Рубакин Н. А. Психология читателя и книги. Краткое введение в библиологическую психологию. Москва : Книга, 1977. 264 с.

15. Татаркевич В. Історія філософії : Т. 1-3 / пер. 3 польськ. Я. Саноцький, О. Гірний. Львів : Свічадо, 1999.

16. Фрідман Т.-Л. Світ плаский. Харків. : Акта, 2008. 676 с.

17. Фрейд 3. Достоевский и отцеубийство / пер. с нем. С. Беляева // Фрейд 3. «Я» и «Оно». Труды разных лет. Книга 2. Тбилиси : Мерани, 1991. 428 с.

\section{References:}

1. Anderson, B. (2001). Uyavlyuvani spilnoty. Imaginary communities. Reflections on the origin and spread of nationalism / translated from English V. Morozov. Kyiv: Krytyka, 272 p.

2. Bernejs, E. (2020). Propaganda. Kyiv: vydavnychyj dim «Svarog», 128 p.

3. Vyndelband, V. (1997). History of Philosophy / translated from German P. Rudyn. Kyiv: Nyka-Centr, 560 p. 
4. Gurevych, S. (2010). Philosophical anthropology: textbook. 2nd edition. Moskva: Omega-L, $607 \mathrm{p}$.

5. Dojch, K. (2006). People, nations and communes // Nationalism: people, nations and communes [anthology; organizers O. Procenko, V. Lisovyj] Kyiv: Smoloskyp, 317-322 p.

6. Kastels, M. (2000). Information age: economy, society and culture. Moskva: GU VShhE, $264 \mathrm{p}$.

7. Krymskyj, S., Pavlenko, Yu. (2007). Civilizational development of mankind. Kyiv: Feniks, 316 p.

8. Mak-Lyuen, M. (2011). Gutenberg's Galaxy: The Formation of the Man of the Printed Book; [trans. from EnglishA. A. Galushky, V. I. Postnikova]. 3rd edition. Kyiv: Nika-Centr, 392 p.

9. Niczshe, F. (1993). So said Zarathustra; The desire for power // translated from German A. Onyshhka, P. Tarashhuka. Kyiv: Osnovy, Dnipro, 415 p.

10. Potyatynyk, B. (2004). Media: Keys to understanding. Series: Media Criticism [Seriya: Mediakrytyka]. Lviv: PAIS, 312 p.

11. Pogorilyj, O. (2018). Max Weber and his classic work / Protestant ethics and the spirit of capitalism / translated from German O. Kyiv: Nash format, $216 \mathrm{p}$.

12. Pochepczov, G. (2018). Propaganda 2.0. Kharkov: Folyo, 796 p.

13. Rassel, B. (1995). Istoriya zaxidnoyi filosofiyi // History of Western philosophy // translated from English Yu. Lisnyaka, P. Tarashhuka. Kyiv: Osnovy, 759 p.

14. Rubakyn, N. (1977) Psychology of the reader and the book. A brief introduction to bibliological psychology. Moskva: Knyga, 264 p.

15. Tatarkevych, V. (1999). History of Philosophy: Volumes 1-3 // translated from Polish Ya. Sanoczkyj, O. Girnyj. Lviv: Svichado.

16. Fridman, T.-L. (2008). The world is flat. Kharkiv: Akta, 676 p.

17. Frejd, Z. (1991). Dostoevsky and paternal murder / translated from German S. Belyaeva // Frejd Z. «Ya» y «Ono». Trudy raznyx let. Knyga 2. Tbylysy: Merany, $428 \mathrm{p}$. 